\title{
抗生物質使用清酒䁔造試験 (その1）
}

\author{
秋山裕一, 山尾和也, 佐々木定
}

（昭和 33 年 3 月 15 日受理）

\begin{abstract}
結 論

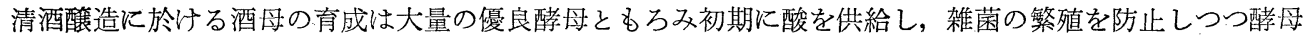

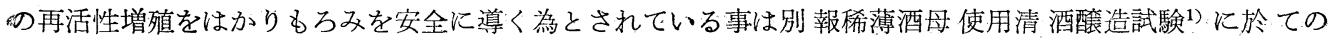
ベ，この考え方の正当性を実証したのである。

清酒酸造は開放䣹酵であるからその安全性を確立する為に酒母が最も重要視された事は種々の事実よりよ く理解される。古来より科用されている生酛, 改良法の山廃酧の複雑であるがその巧妙な理論の利用には全 く驚嗼の外ないが，これは早湧を防止しつつ乳酸菌によつて乳酸酸性とする事によつて雑菌を淘汰し，酔母 の及をを繁殖させる方法で, 欧米でもデルブリュキー方式として実用されている。この乳酸々性の防腐性にヒ ントを得たのが故江田鎌治郎先生の速釀配で仕込当初からの酸性によつて雑菌の侵入繁殖を防止しているわ 好である。更にこの酒母の酸がもろみの初期にも効力を有しているのであつて, このように清酒醽造は開放 醴䤃の安全を確保する為に全コースを酸性に保ち圧倒的多数の酵母によつて運営されているわけである。

しかし最近の抗生物質の考光からすれば酸性により防腐をはからなくても, もろみを安全に導く事が可能 と考光られ, 既に佐藤文がその可能性を指摘している。即ち清酒醸造に大害を及ぼするのはも万みの变敗を ひき沶こす乳酸菌を主とする生酸菌であり, 17)その他には「ぬるり奖」の納豆菌位であるが,これ等の細菌は ペニシリンでその生育を阻止される事が明らかとされているからである。

ペニシリン発見以来戦後の抗生物質の研究発展はめざましく医薬のみでなく, 産業界にも食品の貯蔵性の 增大, 農薬, 飼糧その他各方面に利用されつつある。醴醅工業では米国に於ては糖蜜のアルコール䣹酵に用 いられ, 乳酸菌の污染防止に効果をあげ, アルコールの収率の向上が報告されているが, 2,3) 我が国では経済 的, 法律的に, 又原料関係もあつて加熱殺菌が採用され，抗生物質の利用はあまりなされていない。従つて

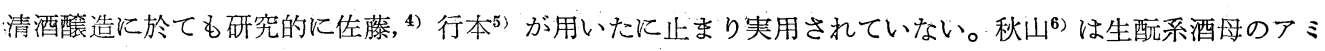
ノ酸の生因についての報告に於て生配に生育する乳酸菌等を抑制する為にペニシリンを用い，十分の効果を 収め得た事を報じた。ペニシリンは酒母中で低温中性状態では相当長期間安定に保たれ，乳酸菌等の生育を 阻止した。しかし酸醳中では相当急速に破壞され，もろみ中では 10 単位は 1 2 日間で消失するものであ 尚。そこで筆者等は乳酸の代りとしてペニシリンを用いる事としたが，その添加量については 2 単位でよい ( 8 単位でほぼ完全) ${ }^{2,3,4,18)}$ といわれるが，別報6)で清酒の酒母は濃厚な為に相当の吸着がおこる事が見ら れたので唏薄酒母を用いたのであるが，一応酒母 $1 \mathrm{~g}$ 当り 50 単位を用いる事とした。即ち 5 斗もと 1 本に 対して約 $4 \mathrm{~g}$ を用いる事になる。

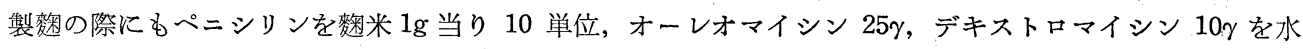
炕とかし床揉時に噴霧し，その微生物及び酵素力を調査し，更に成製酒の成分をイオン交換樹脂により分別 定量しつつあるのでその一部を報告する。

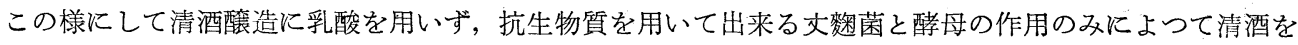
造ろ弓と意図し，大体普通の清酒と殆んど差のないるのを得られた事は興味ある事である。しかし詳細には 雑菌が皆無であつたわけでなく, 味の点であやや「オシ味」酸味にとぼしかつた事, 更に味と成分中の酸区 分の含有率などの関係から香味といら点でも興味のある点ではなからうか。

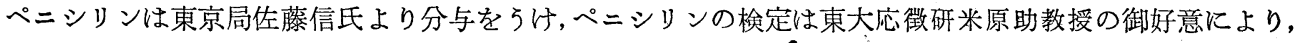
又オーレオマイシン, デキストロマイシンは武田薬品醱酵研究所佐藤喜吉先生より頂戴したものであり, 深 謝いたします。
\end{abstract}

\section{実 験 の 部}

\section{1. 仕込配合}




\begin{tabular}{|c|c|c|c|c|c|}
\hline & 酒母 & 初添 & 仲添 & 留添 & 計(石) \\
\hline 蒸米 & .050 & .210 & .440 & .850 & 1.550 \\
\hline 䴴米 & .025 & .095 & .130 & .200 & .450 \\
\hline 汲水 & .150 & .200 & .550 & 1. 200 & 2. 100 \\
\hline
\end{tabular}

総米 2 石, 稀薄酒母, 汲水歩合 10.5 焚然米, 酒母米 2 割 5 分, 掛米 2 割精白

B. 速酮酒母使用仕込 (21号仕込)

\begin{tabular}{|c|c|c|c|c|c|}
\hline 蒸米 & .100 & .210 & .440 & .800 & 1.550 \\
\hline 麲米 & .050 & .080 & .130 & . 190 & .450 \\
\hline 汲水 & .120 & .230 & .550 & 1.200 & 2.100 \\
\hline
\end{tabular}

上段A 20 号は稀薄酒母で別報々同様 $2,1,6$ (普通は5,2,6) の配合で, 高温糖化前後にペニシリンを加 えた。下段B号は普通速䤑酒母にペニシリンを加えたが, 製麴の際にオーレオマイシン, デキストロマイシ ン, ペニシリン等を用い出来る大無菌憗で仕込む事を目的とした。両者ともアル添及び四段等は行わなかつ. た。

\section{2. 酒母及ひもろみ経過}

ペニシリン添加高温糖化稀薄酒母による仕込は第 1 及び 2 表, 乳酸添加速醸酛による仕込は第 3 及び 4 表 にかかげた。

第 1 表 ペニシリン添加酒母（稀薄高温糖化酒母仕込第 20 号）

\begin{tabular}{|c|c|c|c|c|c|c|c|c|c|c|c|c|}
\hline 月日 & 旦 & 操作 & $\begin{array}{l}\text { 品 } \\
\text { 温 }\end{array}$ & $\begin{array}{l}\text { 皮 } \\
\text { I } \\
x\end{array}$ & 酸 & $\begin{array}{l}\boldsymbol{\gamma} ミ \\
\text { ノ酸 }\end{array}$ & $\begin{array}{l}>ル \\
\geq ー \\
ル\end{array}$ & 直糖 & $\begin{array}{c}\text { ペ= }= \\
\text { yン } \\
\mathrm{U} / \mathrm{g}\end{array}$ & 䤊母 & $\mathrm{pH}$ & 備考 \\
\hline 2. 7 & 1 & 仕込 & 55 & & & & & & 10U添加 & & & \\
\hline & & 冷却 & 30 & 10.5 & 0.2 & 1.3 & & 15.15 & 40U添加 & & 5.4 & \\
\hline 8 & 2 & わき付 & & & & & & & 4 & & & \\
\hline 9 & 3 & & 13 & 10.4 & 0.9 & 0.9 & & & & & 4.8 & \\
\hline 10 & 4 & & 12 & & & & & & 0 & & & \\
\hline 11 & 5 & & 20 & 7.8 & 1.45 & 0.25 & & & & 14500 & 4.4 & \\
\hline 13 & 7. & & 16 & 4.2 & 1.9 & 0.4 & 7.5 & & & 42000 & & 使用 \\
\hline
\end{tabular}

第 2 表 ペニシリン使用仕込試験 醪経過表 (仕込第 20 号)

\begin{tabular}{|c|c|c|c|c|c|c|c|c|c|c|}
\hline \multirow{2}{*}{ 月日 } & \multirow{2}{*}{$\begin{array}{l}\text { 日 } \\
\text { 順 }\end{array}$} & \multirow{2}{*}{ 操作 } & \multirow{2}{*}{ 品温 } & \multirow{2}{*}{$\begin{array}{c}\text { ホ } \\
1 \\
x\end{array}$} & \multirow{2}{*}{ 酸 } & \multirow{2}{*}{$\begin{array}{l}\text { アル } \\
コ ー \\
ル\end{array}$} & \multirow{2}{*}{$\begin{array}{l}\text { アミ } \\
\text { ノ酸 }\end{array}$} & \multicolumn{2}{|c|}{ ペニシリン } & \multirow{2}{*}{ 備考 } \\
\hline & & & & & & & & 添加量 & 測定值 & \\
\hline \multirow{2}{*}{2.13} & - & 初温水教 & 10.5 & & & & & $10 \mathrm{U} / \mathrm{g}$ & $\mathrm{U} / \mathrm{cc}$ & \\
\hline & & 仕込 & 13 & & & & & & & \\
\hline 14 & - & 踊 & 14 & 7.2 & 0.2 & & 0.5 & & 測定不能 & \\
\hline 15 & - & 仲添 & 8.5 & & & & & $10 \mathrm{U}(\mathrm{g})$ & & \\
\hline 16 & 1 & 留添 & 8.5 & & & & & $10 \mathrm{U}(4 \mathrm{~g})$ & & \\
\hline 18 & 3 & & 10.5 & & & & & & 5 & \\
\hline 19 & 4 & & 12 & 5.5 & 0.9 & & 0.25 & & & $\mathrm{pH} 4.5$ \\
\hline 22 & 7 & & 14 & & & & & $10 \mathrm{U}(4 \mathrm{~g})$ & & \\
\hline 23 & 8 & & 13 & 4.6 & 1.6 & 11.0 & 1.0 & & & $\mathrm{pH} 4.6$ \\
\hline 26 & 11 & & 13 & 3.8 & 1.9 & 12.7 & 1.5 & & 測定不能 & \\
\hline 3. 1 & 14 & & 14 & 2.0 & 2.0 & 15.0 & 1.9 & & & \\
\hline 4 & 17 & & 11.5 & -11 & 2.0 & 16.0 & 2.3 & & & \\
\hline 7 & 20 & & 8.6 & -5 & 2.0 & 18.0 & 2.3 & & & \\
\hline \multirow[t]{2}{*}{$\cdot 11$} & 25 & & 6.5 & +4.0 & 2.0 & 18.5 & 2.5 & 直糖2.65 & pH4. 6 & 上槽 \\
\hline & & 上槽後 & 青酒 100 & $\begin{array}{l}\text { 倍濃縮ぺ } \\
2 \mathrm{~kg} \text { 抽出 }\end{array}$ & $\begin{array}{l}=シ リ \\
\text { 物中 }\end{array}$ & $\begin{array}{l}\text { 力価ナ } \\
=シ リ ン\end{array}$ & カ価ナシ & & & \\
\hline \multirow[t]{3}{*}{ 梸酒成績 } & 32 & 2 年 4 月 1 & 日 10 & (30点中) & & (生酒) & & & & \\
\hline & & 6. & $25 \quad 13$ & (54点中) & & （初吞 & & & & \\
\hline & & 11. & $20 \quad 17$ & (33点中) & & 澄明度 & & & & \\
\hline
\end{tabular}

20 号もろみについて

第 1 表の稀薄酒好は高温糖化した点のみが違らが別報”とほぼ同様の経過で, ペニシリン力価は仕达翌日 の湧付には $4 \mathrm{U} ， 4$ 日目には測定不能と急速に分解消失したが以後は添加しなかつた。これは醳母が圧倒的 
第 3 表 抗生物質使用仕込試験 速醸酒母経過（第 21 号酒母）

\begin{tabular}{|c|c|c|c|c|c|c|c|c|c|}
\hline 月日 & $\begin{array}{l}\text { 日 } \\
\text { 順 }\end{array}$ & 操作 & 品温 & $\begin{array}{l}\text { ボ } \\
1 \\
x\end{array}$ & 酸 & $\begin{array}{l}\text { アミ } \\
\text { ノ酸 }\end{array}$ & $\begin{array}{l}ア ル \\
コ- \\
ル\end{array}$ & $\begin{array}{c}\text { ペニシリン } \\
\text { 単位 }\end{array}$ & 酵母 \\
\hline 2. 7 & 1 & 仕込 & 24 & & & & & 50/Ug添加 & \\
\hline 9 & 3 & ふくく & 18 & 17.0 & 2.6 & 2.2 & & 測定不能 & \\
\hline 11 & 5 & & 20 & 15 & 4.4 & 2.5 & & & \\
\hline 13 & 7 & & 20 & 12 & 5.6 & 2.4 & & & \\
\hline 14 & 8 & 枯 & 16 & 10.5 & 5.7 & 2.5 & & & \\
\hline 18 & 12 & & 9 & 8.2 & 6.1 & 2.8 & 12.5 & & 41300 \\
\hline
\end{tabular}

第 4 表 抗生物質使用仕込試験 醪経過表 (第 21 号)

\begin{tabular}{|c|c|c|c|c|c|c|c|c|}
\hline 月日 & $\begin{array}{l}\text { 日 } \\
\text { 順 }\end{array}$ & 操 作 & 品温 & $\begin{array}{l}\text { ボ } \\
\text { \ } \\
\text { メ }\end{array}$ & 酸 & $\begin{array}{l}\text { アル } \\
=- \\
ル\end{array}$ & $\begin{array}{l}\text { アミ } \\
\text { ノ酸 }\end{array}$ & $\mathrm{pH}$ \\
\hline 2.20 & & $\begin{array}{l}\text { 水 桷 } \\
\text { 初添仕込 }\end{array}$ & $\begin{array}{l}10.5 \\
12.5\end{array}$ & & & & & \\
\hline 21 & & 踊 & 14 & 10.0 & 2.2 & & 1.8 & 4. 2 \\
\hline 22 & & 添 & 9 & & & & & \\
\hline 23 & 1 & 添 & 7.5 & & & & & \\
\hline 25 & 3 & & 8.5 & 4.8 & 0.5 & & 1.0 & \\
\hline 27 & 5 & & 10.5 & 3.9 & 1.0 & 7.0 & 0.8 & \\
\hline 3. 1 & 7 & & 10.5 & 3.6 & 1.8 & & 1.3 & \\
\hline 4 & 10 & & 12.5 & 2.9 & 1.7 & 12.5 & 1.1 & \\
\hline 7 & 13 & & 13 & -10 & 2.0 & 14.0 & 2.1 & \\
\hline 9 & 15 & & 12 & -5 & 2.1 & 16.0 & 2.1 & \\
\hline 12 & 18 & & 10.5 & -0 & 2.1 & 18.0 & 2.5 & \\
\hline \multirow[t]{3}{*}{15} & 21 & 上槽 & 8 & +3.0 & 2.0 & 20.0 & 2.6 & \\
\hline & \multirow[t]{2}{*}{ 唎酒成績 } & $\begin{array}{c}4 \text { 月 } 1 \text { 日 } \\
6.25\end{array}$ & $\begin{array}{r}16 \\
5\end{array}$ & $\begin{array}{l}\text { (30点中) } \\
\text { (54点中) }\end{array}$ & 生酒 & & & \\
\hline & & 11.20 & 11 & (33点中) & 澄明度 & 8 & & \\
\hline
\end{tabular}

多数であると考えた事とペニシリンは加えてもすぐ分解されるからとの二点からである。品温経過は比較的 低温としボーメは 10.5 のものが 4.2 と約 6 度しか切らせず,普通の酒母に比すれば驚くほど糖消費はなく, アルコールも $7.5 \%$ と少いが，醥母数は 4 億と普通酒母と全く変らない， $\mathrm{pH}$ は 5.4 から次第に 4.4 迄下 つたが，酸は使用時です $1.9 \mathrm{cc}$ でこれ又製成清酒の酸と同一で普通速醸酛の約 $1 / 4$ にすぎない。

もろみ経過は第 2 表の如く少量仕込の為品温が下り気味であつた。ペニシリンは添, 仲, 留の各仕込水䴹 時にもろみ $1 \mathrm{~g}$ 当り 10 単位添加，更に 7 日目に酸が増加したので更に 10 単位 $(4 \mathrm{~g})$ 加光たが，これは高泡 時の生酸の最も多い時に当つたのであつて加えなくてもよかつたものと思われる。ペニシリン力価は表の如 く醱酵が旺盛な時はほぼ1日で 10U は破壊されてしまうが，留後の醱酵の静かな時にはほぼ 2 日日力価 がある。ペニシリンは全量で約 $10 \mathrm{~g}$ を添加したが，上槽後の清酒中には 100 倍濃縮（抽出）するもぺニシリ ンの力価なく，粕中にもない。即ち清酒粕 $2 \mathrm{~kg}$ を実験農芸化学書7に従つて氷水に懸濁させ 酸性にて酢酸 ブチルで抽出し，溶媒層を中和してペニシリンを水に転溶し，この方法を繰返して 100 倍濃縮したものに もペニシリン力価なく，ペニシリンはもろみの醗酵中にどの様に破壊されたかわからないが完全にその効力 を失い，清酒中にも又清酒粕中にも存在を認め得なかつた。

ボーメの切れ方，アルコールの出方は普通のものと変りないが，酸は $2 \mathrm{cc}$ とやや少く，その乳酸 コハク 酸比等は興味ある問題であるが，後に記す。

製品の成績はアルコール添加を全くしない為に秋になつてやや重く感じるようになり，相当白ボケしたが 大体中位であつた。味はきれいであるがやはり酸味が不足気味でやや「ぼける」感じであつた。

21 号もろみについて

酒母は普通速醸とし，ペニシリンを加えたが，先報でも述べた如くすぐ破壊されている。（第 3 表）本仕込

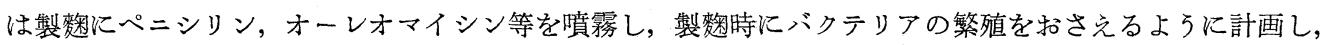
もろみには抗生物質を添加しなかつた。もろみ経過も第 4 表に見る如くやや前急式であるが，成分及び唎酒 成績は普通であつた。これは火入れ直後 $45^{\circ} \mathrm{C}$ 位に下つた時にクラリン $\mathrm{S} 5 \mathrm{~g}$ /石加えたもので初吞切時より 清澄で秋には澄明度 8 と 5 よ5に全くきれいであつて，又クラリンSを長期間入れて怙いたが為に品質が 
劣化したように見られない。

\section{製躷中でのペニシリンの変化}

ペニシリン $\mathrm{G} . \mathrm{K}$ 塩を水にとかし粷米 $1 \mathrm{~g}$ 当り $10 \mathrm{U}$ を種数撒布時に噴霧した。仕事後に採取して, 抽出 しペニシリンカ価を測定すると第 5 表の様に㛫菌が旺盛に繁殖しはじめる頃に急激に消失し, これは 2 回繰 返したがこのようであつた。

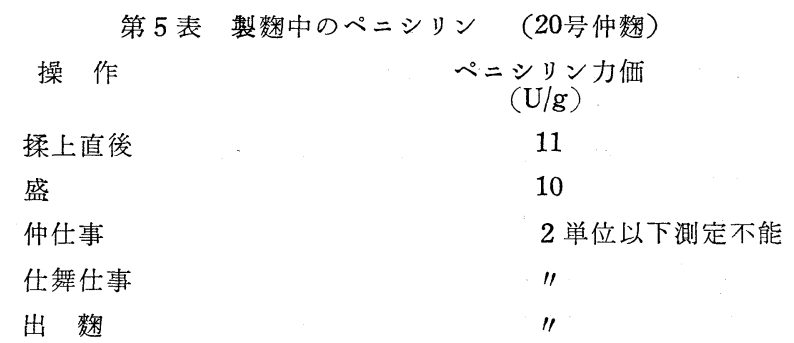

筴米 13 升 ペニシリンを $50 \mathrm{cc}$ の水にとかし噴霧する

製桷及びもろみ中のバクテリアについて

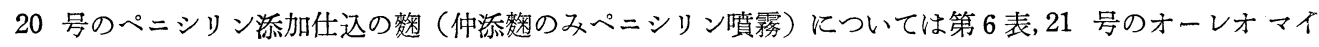
シン，デキストロマイシンを噴霧した㛫については第 7 表に示した。

第 6 表 20 号掛整中のバクテリア

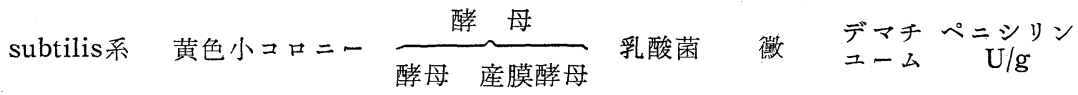

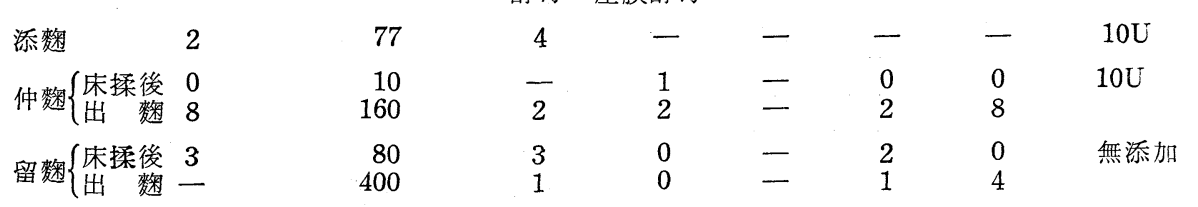

憗 $1 \mathrm{~g}$ 中の細菌数は $\times 5000$

第 7 表 21 号掛整中のバクテリア subtilis
系

乳酸菌酵母

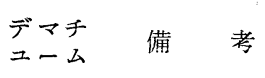

2.オーレオマイシン

$10.3 \mathrm{~g}$ 撒布 $25 \gamma / g$ 白米

細菌コロニー9

2 デキストロマイシン $200 \mathrm{mg} 50 \mathrm{cc}$ とかし 撒布 $(10 \gamma / \mathrm{g})$

$$
\text { コロ }=-11
$$

1

$$
\text { ペニシリン } 200 \mathrm{mg}
$$
$50 \mathrm{cc}$ 水にとかし撒 布 $10 \mathrm{U} / \mathrm{g}$

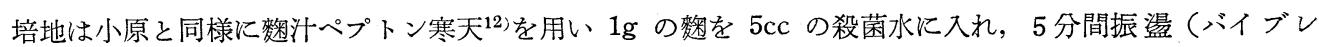

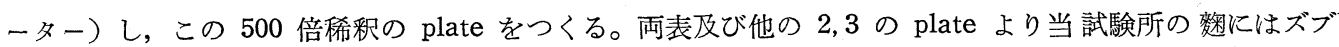
チリス系は少く, 黄色小コロニーの球菌が非常に多く現われる。この菌はペニシリン, 及びオーレオマイシ

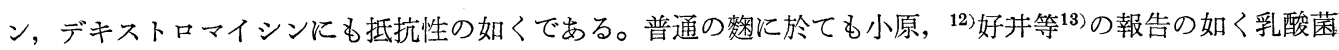
のコロニーが見られなかつたのは如何なる理由かわからないのであるが，操作法或は培地に欠点があつたの 


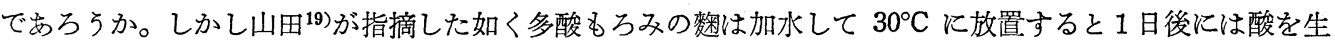
成しはじめる。これは生酸菌の存在を証するものであるが，これにならい抗生物質を製棶米時に噴霧した掛整 についてテストを行つた。第 8 表に見る如く他所の㮅及び抗生物質無添加の当所の茠は 24 時間後にはいず れも 1〜2cc の滴定值を得たがペニシリン，オーレオマイシン噴霧のものは全く生酸が見られず，デキスト ロマイシンが 36 時間後に生酸を見るにいたつている点からすれば，これ等抗生物質は製效時の生酸菌の繁

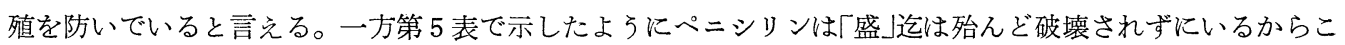
の間に生酸菌の繁殖を扣さえているものと思われる。仲仕事以後は憗菌の繁殖が相当盛になるし又表面が乾

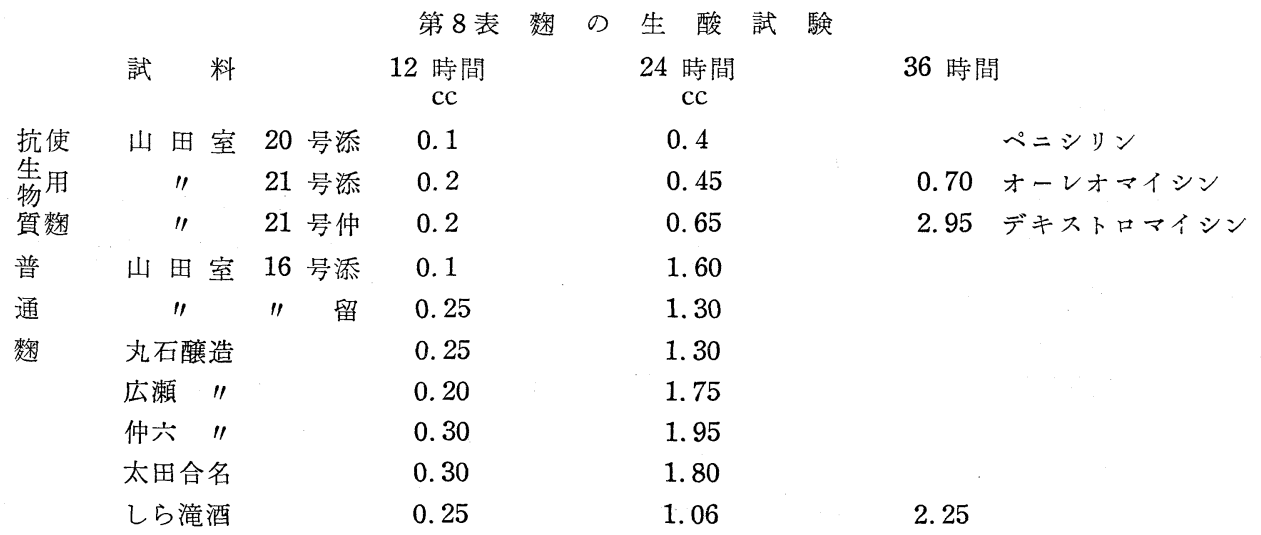

試験法：䴹 $20 \mathrm{~g}$ に水道水 $100 \mathrm{cc}$ を加兄 $30^{\circ} \mathrm{C}$ に保ち各時間に $10 \mathrm{cc}$ 採取, $\mathrm{N} / 10 \mathrm{NaOH}$ の滴 定值にて表示。

燥して来るので他の細菌などは繁殖しにくくなる事も理解されるが，恐らく細菌は床期間中に於いて繁殖す

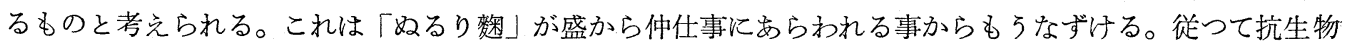
質は後半には効力を失するが床揉みに用られば完全にその効果をあげ得るといえ，この様な事は酒母やもろ みでもいえる事と考えられる。上記の事実から分離法に多少の欠陥はあつたかも知れないが抗生物質使用に

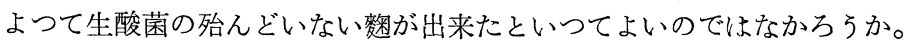

もろみについては酵母を抑学る為にトリコマイシン $10 \mathrm{U} / \mathrm{cc}$ 加えたもので plate したが，バクテリアは20 号及び 21 号にはあまりない(第 9 表)。他の抗生物質を用いないもろみ 16 号でもあまり発見されなかつた

第 9 表 もろみ中の細菌

2 月 22 日 調ベ subhilis系黄色コロニーその他

$\begin{array}{lccc}16 & 2 & 0 & 0 \\ 20 \text { 号 } 7 \text { 日目 } & 16 & 0 & 1 \\ 21 \text { 号仲添 } & - & 120 & 1 \\ 2 \text { 月 } 26 \text { 日 } & \text { 調べ } & & \\ 16 \text { 号 } & 2 & 0 & 22 \\ 20 \text { 号 } 11 \text { 日目 } & 0 & 0 & 0 \\ 21 \text { 号 } 4 \text { 日目 } & 2 & 26 & 6\end{array}$

3 月 7 日 調べ

20 号20日目 0

21 号13日目 0

25

0

憗汁, 炭酸石灰寒天培地とペプトン寒天を用 5 , 両者ともトリ ニマイシン $10 \mathrm{U}$ 添加し酵母を抑える。表はペプトン培地のもの を示す。(娄汁も大美なかつた)

もろみ $1 \mathrm{~g}$ 中の細菌数は $\times 1000$
が，正常もろみでは特にもろみ後期には あまり雑菌はいないものと見える。各地 のもろみの細菌について別報で記すが， 工場で全く異るもので，明らかに憗に由 来すると思えるものもある。

ペニシリン等の抗生物質を噴霧製慗し た棶米の酵素力価は島田等 ${ }^{15}$ の方法に従い 第 10 表で示したが普通の䴴と差は見出 せない。

\section{ペニシリン使用仕込酸造清酒の成分}

1，イオン交換樹脂による分別，清酒

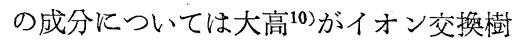
脂を用い広沉な成分研究を行つているか ら，これにならい Amberlite IR-120 と IRA-400 とを通して窒素区分と酸区分 と糖区分とに分けた。

2 , 酸区分, Amberlite IRA-400 吸着 区分を $\mathrm{N}-\mathrm{NaOH}$ にて抽出し，IR-120 にて遊離酸とし水蒸気蒸溜により揮 発酸を先ず分け，不揮発酸を濃 縮し，エーテル抽出し，その抽出区分についてコハク酸と乳酸を Ba 塩のアルコール溶解度によつて、分別 


\begin{tabular}{|c|c|c|c|c|}
\hline \multicolumn{2}{|c|}{ 仕込番号 } & $\begin{array}{l}\text { 抗生物質 } \\
\text { 種類 U/g }\end{array}$ & $\alpha$-amylase & $\begin{array}{l}\text { S-amylase } \\
\text { glucose mg }\end{array}$ \\
\hline \multirow{3}{*}{20} & 添 & ペニシリン 10U & 10 & 15.3 \\
\hline & 仲 & ペニシリン $10 \mathrm{U}$. & & \\
\hline & 留 & 無添加 & 15 & 14.3 \\
\hline \multirow{3}{*}{21} & 添 & オーレオマイシン & 21 & 12.6 \\
\hline & 仲 & デキストロマイシン & 23 & 12.1 \\
\hline & 留 & ペニシリン $10 \mathrm{U}$ & 23 & 8.5 \\
\hline \multirow{3}{*}{16} & 添 & 無添加 & 8 & 22.8 \\
\hline & 仲 & $\prime \prime$ & 10 & 13.3 \\
\hline & 留 & $\prime \prime$ & 12 & 15.0 \\
\hline
\end{tabular}

し, 清酒 $2.5 l$ よりコハク酸 $1.1 \mathrm{~g}$. 乳酸 $0.9 \mathrm{~g}$ を得た。その酸比は $1: 0.8$ になるが揮発酸部にも乳酸が相 当移行しており,ここょり得られた乳酸が $0.59 \mathrm{~g}$ でこれを加兄ると乳酸の方が多くなる。酢酸は $0.52 \mathrm{~g} / 2.5 l$ 。 この様に大体普通清酒と大した相違ない,8,9,10) 結果で與味深いが，この酸区分の更に詳細については目下榆 討中であるから，続報する。

3, 糖成分, 柴崎11)の方法によつてセライト活性炭素クロマトグラフによつてアルコール濃度をちがえて 溶出し, ペーパークロマト法によつて分別し，グルコース区分とイソマルトース区分のみについてフェーリ ングの還元量より測定した。

$\left.\begin{array}{llr}\text { 原酒直糖 } & 2.880 & \\ \text { 試料直糖 } & 2.860 \mathrm{~g} & \text { (イオン交換樹脂流下後) } \\ \text { グルコース } & 2.487 & 86.9 \% \\ \text { イソマルトース } & 0.156 & 5.5 \%\end{array}\right\} 92.4 \%$

上記のように原酒の糖分は㱠んど損失なくイオン交換樹脂塔より流下し回収された。糖組成についてはこ れ迄の報告16)よりややグルコースが多いようであるが大体一致している。

綜括

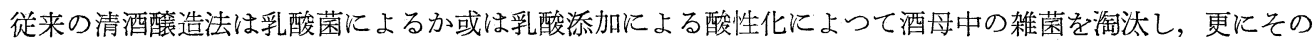
酸性によつてもろみの酕酵を安全にみちびいている。この酸性を保つ代りに抗生物質を利用して清酒䁔造試 験を行つた。清酒䁔造でもろ久が変調を来たすのは大抵生酸菌主として乳酸菌によるものである17)から，こ れ等を特さ光しかも最も得やすいペニシリン（オーレオマイシンも用いたが）を酒母及び㛫の製造に利用し て安全に清酒を䁔造した。

醸出の清酒の成分はアルコール 18.5 度, 清酒メーター $(+) 4.0$, 酸 $2.0 \mathrm{cc}$ ( コハク酸として $0.118 \%$ ) 直 糖 $2.88 \%$ pH 4.6 。一般成分としては酸が少いのみで他は同じょうである。味は酸が少い事からかきれい であるが酸味がややたらず括し味にとぼしかつたが，成績は所内唎酒で年間中位よりやや上であつた。

ペニシリンはるろみの酸酵中に容易に破壞消失し, るろみに全重約 $10 \mathrm{~g}$ のペニシリンを用いたが清酒中 にも又粕中にも見出し得なかつた。製婪時に用いたものは㛫菌の繁殖が盛になる仲仕事頃に急激に消失して ゆくが，細菌に対しては生酸菌の繁殖をほぼ完全に抑制した。これはオーレオマイシンについても同結果で 岕つた。

このよ5にして出来る丈細菌のいない䊍を用い，酒母及びもろみへの雑菌侵入をペニシリンで防ぎ，従来 と異つたやり方で清酒を醇造して得た清酒の酸組成, 桾分組成をしらべ, 酸組成は従来のものと大差ないよ うな結果が得られたがこれについては更に他の清酒とも比較し検討したい。

文

献

1) 山田正一, 秋山裕一, 山尾和也, 佐々木定: 本誌, 53, 3号 (昭33)

2) W. Borzani \& E. Aquarone : J. Agr. Food. Chem. 5, 612 (1957)

3) W. H. Day, W. C. Serjak • : J.agr. Food. Chem, 2, 252 (1954)

4) 佐藤信 : 本誌 50,129 (昭 30 )

5 ) 行本向志: 本誌, 52,186 (昭 32 )

6 ) 秋山裕一：農化, 31, 913 (昭32) 
7 ) 秋山裕一: 実験農芸化学, 256 頁, 朝倉書店 (昭28)

8）川野義男，川端修：䤊工，31，184，434（昭28）32，411，413（昭29）

9) 猿野琳次郎, 阿野藤七 : 醱工 : 32, 323 (昭29)

10) 大高洋一：農化，29,877〜83 (昭30)

11）柴崎一雄 : 農化，29，764（昭30）

12) 小原䉷 : 本誌, 50,226 (昭30)

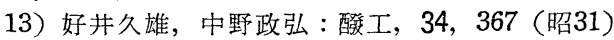

14) 鈴木明治, 布川弥太郎等 : 本誌, 52, 222 (昭32)

15）島田四郎，杉田修，水本邦彥，蔭山公雄，醱工，32，68（昭29）

16) 山田正一：醱造分析法, 383 頁

17) 秋山裕一, 中山大樹 : 本誌, 46, 110,260（昭26）

18) F. B. Strandskov. \& J. B. Bockelmann : J. Inst. Brewing, 61, 237 (1955)

19) 山田正一: 本誌, 52, 586 (昭32)

\title{
いわゆる蛋白混濁清酒（白ボヶ清酒）に関する研究（第 6 報）
}

\author{
酵素剤による清酒混濁の沈停効果について
}

井上幸男, 川崎 恒, 小巻利章, 屋代光良, 松葉 量

(昭和 33 年 1 月 27 日受理)

\section{緒言}

筆者等は, 先に Bacterial Amylase 及び Proteinase を主体とする酵素㓮によつて, 清酒中の混濁物質 が凝固沈停する現象を認めたが，1) それは主として Proteinase 作用によるものと想像した。

その後, 混濁沈停の機構については多くの研究者によつて混濁物質の化学組成, 混濁生成原因等, 多角度 から研究がすすめられて来たが2-7) 筆者等はその後種々の現象から沈停 作用を単なる Proteinase 作用と考 えることに疑義を持ち，これについて検討するために 2.3 の実験を行つた。

\section{実験}

混濁沈停に用いる酵素剤は出来るだけ純粋単一な酵素と言う建前から下記のものを主として用いた。

Crystalline Bacterial Amylase (Am.):

工業生産により得られた B. subtilis の培養液より澱粉吸着法, イオン交換樹脂脱色処理等の操作で結晶: 化した Crystalline Bacterial Amylase を用いた。このものの1g当りの活性度は $200 \times 10^{4} \mathrm{DUN}$ である。 opt.pH

Crystalline Bacterial Alkaline Proteinase(A.P.) :

上述の Amylase 生産の際同時に得られる Proteinase で港粉吸着法で Amylase を除きアニオン交換樹 脂による脱色, カチオン交換樹脂による選択的吸着溶離等の操作を得て結晶化したものを用いた。opt. pH. が 8.0 附近であるから一応 Alkaline Proteinase と仮称する極めて安定な Proteinase である。

$1 \mathrm{~g}$ 当りの活性度は $150 \times 10^{4} \mathrm{DUK}$ である。

Bacterial Neutral Proteinase (N.P.) :

上述の二酵亲生産に用いたと同一の菌株を用いて培養条件を変えることによつて仮称Neutral-Proteinsae が多量生産される。この培養液より澱粉吸着により Amylase と分離し potato の Proteinase Inhibitor を添加, Alkaline Proteinase を失活させ, 更に硫安によつて Alkaline Proteinase Inhibitor Complex を 分別して除き更にアニオン交換樹脂で脱色, 後透折しアセトン粉末としたものを用いた。opt. pH は 6.5 附 近で極めて不安定な酵素でめる。 